\title{
No Formal Schooling
}

National Cancer Institute

\section{Source}

National Cancer Institute. No Formal Schooling. NCI Thesaurus. Code C67122.

Indicates that a person has never attended an educational prog ram or formal schooling. 